\title{
Organisational Pressure on Quality-of-worklife of Women in Tertiary Institutions in Lagos State, Nigeria
}

\author{
Mobolaji Ogunsanya $^{1} \&$ Adebisi Olorunfemi $^{2}$ \\ ${ }^{1}$ Department of Educational Management, University of Ibadan, Nigeria \\ ${ }^{2}$ Department of Educational Management, Lagos State University, Nigeria \\ Correspondence: Adebisi Olorunfemi, Department of Educational Management, Lagos State University, Nigeria. \\ Tel: 234-808-098-4578. E-mail: bisiyinka@gmail.com
}

Received: June 28, 2012 Accepted: July 26, 2012 Online Published: September 26, 2012

doi:10.5539/ies.v5n6p36 URL: http://dx.doi.org/10.5539/ies.v5n6p36

\begin{abstract}
An approach to motivation in the contemporary world of work is the implementation of Quality-of-Worklife (QWL) programmes, which is aimed at easing the pressures faced at work by employees. Quality-of-Worklife is a philosophy of improving productivity by providing workers with the opportunities required to put in their best at work, without jeopardizing their personal self improvement and responsibilities at home. The effectiveness of organisational factors and QWL programmes in the Nigerian tertiary institutions is under-researched. This study, therefore, investigates the organisational pressure on Quality-of-Worklife of women in tertiary institutions in Lagos State, Nigeria. It is a survey of the ex-post facto type. 3,640 senior cadre women working in the four purposively selected degree awarding institutions in Lagos State (University of Lagos, Lagos University Teaching Hospital, Lagos State University and Lagos State University Teaching Hospital) and their managers formed the population. Out of these, 1000 women and 19 managers were randomly selected as sample. A QWL survey and structured interview made up the instrument. Four hypotheses were tested at 0.05 significance level. There were significant differences among the institutions in the compliance to International Labour Organisation (ILO) conventions and in the Quality-of-Worklife of their women workers. Moreover, there were significant relationships between QWL and sources of pressure and QWL and organisational pressure. Factors such as salary, health-care benefit, day-care services, recognition, workload and others, influenced QWL of women. Government and management committees of the tertiary institutions should ensure the reduction of organisational pressure and promote high QWL of women workers, in other to improve on their productivity and promote organisational growth.
\end{abstract}

Keywords: quality-of-worklife, organisational pressure, sources of pressure, sources of satisfaction, productivity, tertiary institutions, Nigeria

\section{Introduction}

World Labour Report, in Martino (1993), noted that stress has become one of the most serious health issues of contemporary times, which employers and governments have started to assess the financial damage. Job stress in the United States (U.S.) for instance, has cost industry an estimate of about US\$200 billion annually, through absenteeism, diminished productivity, compensation claims, health insurance and direct medical expenses. In the United Kingdom (U.K.) also, stress was reported to likely cost up to 10\% of GNP annually, through sickness, poor productivity, staff turnover and premature death. In addition, from a study conducted on Canadian workers, it was estimated that work-life conflict which results to stress on the job costs Canadians approximately $\$ 4.5$ to $\$ 10$ billion per year (Duxbury\&Higgins, 2003). International Labour Organisation (ILO) calls stress a worldwide problem and claims that job related stress has risen from $5 \%$ to $15 \%$ of all occupational hazards and is still rising (Trainer, 2003). Stress has been found to be responsible for physical ailments like hypertension, peptic ulcer, headaches, asthma, kidney and liver diseases, to mention a few. Also, jobs experience; increasing absenteeism, reducing productivity and low team spirit.

In spite of the various ILO conventions and recommendation made in favour of women workers, the problems of working women still persists world-wide, especially in developing countries like Nigeria. For example, there are still several ways by which women are being discriminated against, which invariably pose challenges or pressures at work. There seems to be inequality in the areas of; job-placement, promotion, participation in decision-making, 
responsibilities and opportunities, trade union activities and job retention. The rate of women unemployment is likely higher than that of men, because whenever a downsizing or retrenchment is to take place in an organisation, women are mostly affected(Jeremigbe 1992, Huyer 1997, Vukor-Quarshie 2002).

The Quality-of-Worklife(QWL) of women seeks to improve the plight of women in the workplace and is a measure of how well they can improve their productivity by having the opportunity to use their special abilities, pursue self-improvement, identify with the organisation and humanize the workplace. Most Nigerian women workers still have to struggle with keeping their jobs, the home, and improving on their career. Some advanced countries have introduced QWL programmes, to alleviate the problems of workers at the workplace, but the Nigeria government and industries have not done much in this direction. Hence this study is geared towards finding out how far managers and workers in Nigeria has grown in their awareness and implementation of QWL and what efforts are being made to promote it, especially for women workers. Also, a comparison of federal and state owned degree awarding tertiary institutions in Lagos State would throw more light on the extent of awareness and implementation of QWL programmes.

Sequel to the problems stated earlier, the following research question is to act as a guide for this study: 'Does the degree awarding tertiary institutions in Lagos, differ in organisational pressure and quality-of-worklife of their women workers?'

\subsection{Hypotheses}

To proffer solution to the research question these hypotheses are tested;

$\mathrm{H}_{\mathrm{o}}{ }^{1}$ : There is no significant relationship between QWL and sources of pressure of women workers in tertiary institutions in Lagos State.

$\mathrm{H}_{\mathrm{o}}{ }^{2}$ : There is no significant relationship between QWL and Organisational pressure of women workers in tertiary institutions in Lagos State.

$\mathrm{H}_{\mathrm{o}}{ }^{3}$ : There is no significant difference in the level of compliance to the ILO conventions as it affects women in the different tertiary institutions in Lagos State.

$\mathrm{H}_{\mathrm{o}}{ }^{4}$ : There is no significant difference in the QWL of women workers in the different tertiary institutions in Lagos State.

\section{Review of Related Literature}

Human resources have been tagged as the most important feature in any organisation. It has been observed that a lot of extraneous factors do work against the high productivity of workers. Some of these factors includes, family responsibilities, social interaction with co-workers, societal responsibilities, inadequate remuneration and organisational politics, among others. All these can amount to pressures on the worker, creating stress, and impacting negatively on the level of job satisfaction. The resultant effect of these are poor job performance and low productivity.

Since the level of productivity is dependent to a great extent on the human resources, it becomes imperative for the workers to be placed in a motivating working condition. The working environment is not limited to just the physical environment, but also the socio-economical, psychological and political environment. This is why the International Labour Organisation (ILO), over a century ago, had come up with conventions and recommendations geared towards promoting the working environment of workers world-wide. The case of women workers becomes of greater concern because they have always been in the minority in the workforce and as such, have suffered more within the work environment. Women workers have some peculiarities which have not been properly considered by the work organisations and this led to the ILO constructing specific conventions and recommendations in their favour.

In spite of international conferences and enactment of labour laws in favour of women workers, it is still observed that the QWL of women workers is not yet desirable, particularly in developing countries like Nigeria. The stressors such as job conditions, sex discrimination, heavy work load, poor remuneration, frustrated ambition, poor welfare package, marital conflict, non-participation in decision making and much more, are still very imminent and they converge to form organisational pressures on women workers. In the midst of these pressures, "Could working women successfully meet expectation at work, while pursuing a virile career and maintaining concord within the family?" Definitely yes, if factors such as organisational pressure, time pressure, work-scheduling, decision making, communication and work relations correlate positively with their QWL. 


\subsection{Organisational Pressures and Their Impact on QWL}

The ILO's World Labour Report of 1993 presented some job stressors, their contributing factors and possible consequences. Considering the report, it is observed that the women workforce is more hit by these job stressors. This gives a leading to the importance of the effect of pressures on workers. Martino (1993) also asserted that programmes to combat stress at the workplace are proving far more cost effective than might have been imagined. He concluded that, when workers have less stress and more variety and satisfaction on the job, everybody profits; that is, workers, the Organisation, the economy, and the society as a whole. To buttress the fact that pressures at the workplace is of much concern and particularly for the working women, Seguret (1993) also had this to say:

'having at once a job and family responsibilities is now the norm. But to assume increasing responsibilities on the job, in other words 'to make a career'-is this really possible? Everything is fine as long as the enterprise understands that most of its employees have a family and that in the daily routine of family life, the man must function as an active partner'.

The above observation is still very relevant today in the lives of many working women. The pressures at work and home do not give them room to attain managerial positions and as such do not allow them to exhibit their highest level of productivity. Moreover, according to Oshodi (1997) the lack of or inadequate provision of facilities within the organisation to help reduce stress and distractions from work, is another major problem. Quite a number of nursing mothers have to either legally or illegally get out of work early to collect their babies from the day-care centers a distance away from work. In some cases, that put an end to the day's work, while in some, the presence of such babies in the office creates distractions, not only for the mothers, but also for other workers. In organisations where the mothers cannot take time away from work to collect their babies before the close of the work day, the mother runs the risk of not being able to imbibe proper training into the child during its developmental stage since the child would most of the time be under the care of a house help.

The United Nations Department of Economic And Social Affairs, Division for Sustainable Development (2004) asserted that in order to achieve full, equal and beneficial integration of women in all development activities, in particular Nairobi,

"programme to promote the reduction of the heavy workload of women and girl children at home and outside, through the establishment of more and affordable nurseries and kindergartens ---- social support systems and services, including day-care facilities and parental leave have to be put in place by the government, employers and other relevant organisations",

This also applies very much to the Nigerian situation.

\subsection{Time Pressure on $Q W L$}

One of the reasons why there are still so few women at the top management positions is due to time pressure and excess workload at work, which if coupled with workload at home, makes climbing up that managerial ladder a herculean task. Weinstein (2004) narrated the ordeal of Brenda Barnes, the president and chief executive of the North American arm of PepsiCo, who concluded that "when you talk about those big jobs, those CEO jobs, you just have to give them your life: you can't alter them to make them accommodate women any better than men. It's just the way it is". There are so many women in the same cross-road of whether to pursue their career to the maximum limit or 'soft-pedal' in order to give the family considerable and required attention. In situations like this where the workload or time spent at work is amounting to pressure, the QWL of the women worker will be at the lower ebb.

In a survey conducted on QWL in Canada by Duxbury and Higgins (2005) it was found that one of the major organisational factors that puts much pressure on the level of QWL of women workers is the role overload. This is referred to as the number of hours one puts in per day; meanwhile the workplace culture encourages long-hours of work including unpaid overtime. Failure to put in such long hours is tantamount to loss of rewards, such as promotion. Women workers tends to be the victims of such workplace culture due to obvious unwillingness to put in unpaid overtime while they have family responsibilities calling for their attention. Hence, the male workers will be getting rewarded with promotion while the female workers get stagnated.

\subsection{Work-scheduling and $Q W L$}

One of the major organisational factors impinging on QWL is the work-scheduling. The traditional eight hours per day work hours, has been found not to contribute to high performance on the part of some workers. Some workers, either on health grounds or domestic demands, cannot put in the required eight (8) hours, or not at the scheduled period of the day the organisation has fixed the time. Such workers would engage in more absenteeism, sick leave than normal, thus affecting negatively the productivity of the organisation. 
It is reported that many companies have found that coming up with programmes to help employees balance work with outside needs, pressures and interest, can make them realize benefits in increased productivity and reduced turnover (Business for Social Responsibility, 2005).

In a study conducted by American Business Collaboration (2006) it was discovered that after salary, the factor which contributes positively to job satisfaction for people in their 30s was flexible work options for salaried men, while salaried women opted for worklife balance which of course also include flexibility in the work schedule.

The above positions are positively supported by Jeremigbe (1992) in a study that attempted to identify the critical factors constraining the entry, advancement and/or mobility of women particularly to top management position in Africa, using Nigeria as a text case. In concluding the study, one of the strategies prepared for enhancing the status and advancement of women is part-time work and flexible working hours. In her words Jeremigbe (1992) asserted:

'Part-time Work And flexible Working Hours; these are additional possibilities that would enable women to combine the onerous task of motherhood with their careers and both the employer and the employee would benefit from such arrangements. These options will also prevent women from making choices between their families and careers, and young children of working mothers would cease to be subjected to maternal deprivation for as long as 8-10 hours per day, 5 days a week'.

Moreover, it was found that excess workload and pressure do inevitably lead to job stress and poor performance of teachers/lecturers in the school system. Suggestions made by Adepoju (2001) as part of the organisational stress management strategies in order to reduce incidences of stress and thus low performance on the part of teachers are, "ensuring that workers have job satisfaction by giving them incentives, motivation and reducing their workloads, provision of liberal time-off and vacation policies..."

Working at home, or in some cases, in a designated centres close to home called telecentres, is beginning to gain prominence. The United States, like Nigeria, is a society overwhelmed by pollution, traffic jams and seemingly endless commutes to work. Time spent with families is often minimal and so they looked to telework as one solution to these problems. In the U.S., government still fund projects that would enhance the use of teleworkers and encourage telecommuting as a work option, because it is believed that the option is still grossly underutilized. The USA Congress in return, in an effort to promote telecommuting, included additional telecommuting provisions in recent legislation.

Telecommuting is found to provide numerous benefits to government, employers, employees and the society as a whole. It reduces absenteeism, improves productivity and performance, enhances recruitment and employee retention, reduces the cost of office facilities and their maintenance parking services and some other employee office services. On the part of the employee, telecommuting saves time and money spent on the movements to and from work place especially in a heavy traffic city like Lagos. In addition, telecommuting reduces stress derived from movement to and from work. It makes it easier for employee with disability who wants to work, avoid the hassles and other difficulties of commuting. It also makes it easier for employees who are recovering from work-related injuries or who have continuing health problems or pregnant/nursing mother to work a modified schedule without coming into the office. Most importantly, it gives employees the flexibility to better balance work, family and non-work responsibilities, which is increasingly important as more and more employees find themselves caring for aging parents and for children. Telecommuting is advantageous to the society, because it will reduce traffic and air pollution caused by cars, and invariably conserves fuel consumption. With telecommuting everybody benefits-the employee, the employer, the government and the society.

\subsection{Decision Making, Communication and QWL}

Policies and organisational rules are meant to guide workers on their job activities, such that work environment could experience a peaceful climate. However, it has been observed that many, a times, rather than these organisational policies engendering peace, they tend towards crisis, disaffection and ultimately low productivity. The reasons attributed to the negative impact of these policies include, the decision-making process and the communication system.

In recent times, that is, in contemporary management practices, it is not only the management board who contributes to decision making in an organisation. The involvement of more groups outside management is being encouraged. The 'Total Quality Management' (TQM) management theory is a promoter of more involvement of different groups of both the employees and employers in decision making. In view of this, decision making participation is an integral part of QWL. 
It has been observed that issues concerning women at work do not usually receive much of women's involvement in the decisions on it. Niombo (2006) reported that, 'worldwide, women are under-represented in all decision making structures on information communication technologies (ICT) regulations and policy institutions, ICT ministries and management boards in private companies". It was concluded that there should be efforts at building women's capacity to control the decisions that affect their lives.

In support of all the above reports is the outcome of a study carried out on participatory decision making in some tertiary hospitals by Ogbimi (2003). According to him;

'Since the crux of management work is decision making, the sense of belonging and importance of organisation is provided when occupational groups working in the same system participate in decision making which concern their workplace'...

It was discovered from this study that more females had feelings of invisibility and isolation from participatory decision making.

In addition to the reports on decision making and QWL, is the write-up based on the study of Women in Nairobi, by the United Nations Department of Economics (2004). It was reported that the international community has endorsed several plans of action and conventions for the full, equal and beneficial integration of women in all development activities. It was concluded that the effective implementation of these programmes will depend on the active involvement of women in economic and political decision-making.

Among the objectives proposed for national governments were; to formulate and implement clear governmental policies and national guidelines, strategies and plans for the achievement of equality in all aspects of society, including the promotion of women's literacy, education, nutrition and health, and their participation in key decision-making positions and in management of the environment. Governments are expected to take active steps to implement measures to review policies and establish plans to increase the proportion of women involved as decision-makers, planners, managers in the design, development and implementation of policies and programmes for sustainable development.

In the effort to improve on the quality- of- worklife of workers, it was found that there is the problem of employee effective communicating to employers. Gilbert (2006) stated that, 'As every company knows, employees are its greatest resource. It's more than a shame, then, that many workers are either not encouraged or are afraid to speak up and communicate ideas at work'. This leads to the employers loosing valuable knowledge and experience, and their companies gets weaker for that loss. It was further noted that '.. leaders are inherently important to the improvement-oriented voice process-because leaders are the targets of voice'. If leaders send signals that they are open, interested, and willingly to act on subordinate voice, it is logical to expect that subordinates' motivation to do so will be increased. On the other hand, where subordinates perceive leaders' behaviour to indicate it is either unsafe or futile to speak up, they are less likely to do so. The importance of communication to QWL was also affirmed by Wyatt and Wah (2001), stating that 'achieving some level of personal growth may be quite related to the quality of communication in the organisation. Amabile (2002) also suggested that managers should try to avoid or reduce the obstacles to creativity but enhance the stimulants to creativity on the part of employees, which include putting together diversely skilled teams that communicate well.

\subsection{Work Relations and QWL}

In California State University, as reported by Martin (2006), the usefulness of QWL in resolving industrial relations problems has become very evident. It is noted that the future of public sector labour unions and management is one of increased collaboration. However, it has been observed that, during the past two decades, public sector and management have continually been at ebb over issues relating to compensation, benefits, overtime, and so forth. Naturally, agreeable accommodation for both parties has been difficult to achieve. It is cognizant of this problem that public labour unions and government agencies have begun to implement QWL programmes in order to help mitigate negotiation issues; this has recorded high level of success in Western Europe, Japan and United States.

The important tactics used in QWL methods is to promote approaches in problem-solving. In utilizing QWL methods, public labour and management negotiations have resulted in creating an atmosphere of collaboration and respect which has helped in resolving disputes.

Harvard University (2002) released the statement regarding the university's employment and contracting policies. It is note worthy, that it was a committee that came up with this policies and the final report of the policy which had some recommendations were voted unanimously by a committee composed of students, faculty, union 
representatives and senior administrators. The committee recommended significant wage increases within the context of collective bargaining. Also, the committee urges the University to clarify the values that govern employment on campus and to adopt measures to improve the quality of work life for all workers.

Based on the committee's recommendations, the University decided to strengthen collective bargaining relationships with unions representing workers in the service sectors, and continue to respect the rights of workers to organize and seek union representation.

In his submission, Matanmi (2007) concluded that employment relationships in Nigeria's complex organisations will endure, particularly when such relationships are founded on some parameters which includes:

- $\quad$ Equity and fairness

- Humanistic working conditions and environment

- A prevalent employment practice in the work organisations that are primarily targeted at the attainment of QWL

- The Embrace of flexibility in collective relations (such as the choice of more deregulated/decentralized structures of workplace management

- A Faithful attention by operators and managers of formal work organisations to the work organisational factors.

\subsection{Quality of Worklife and Productivity}

Worklife is an exploration of the relationship between work, family, and personal life. Thus, the QWL programmes are geared towards enhancing a cordial relationship between home and work and as such achieve a steady increase in productivity. In the opinion of Gallagher (2001), finding the right balance between work and a personal life is a life-long challenge for many individuals. If a proper balance is not struck between home and work, productivity will certainly be affected. Business Owner's Toolkit (2001) argued that,

while factors within your business, such as the equality of equipment, the management of materials flow, and general economic considerations (e.g. inflation or recession), can affect your business profits, the extent to which your business realizes a profit from its activity depends largely upon the quality of your employee's performance....'

In view of this understanding of productivity, it is then imperative for any employer to ensure that the employee's performance is highly enhanced, by providing the enabling environment, by identifying problems that might stand in the way of high productivity such as absenteeism, turnover and general low morale. The employer could also share the vision and mission of the business or organisation with the employees. Some level of autonomy or power could be given to the employers, while risk-taking could also be encouraged if it is geared towards helping the organisation reach its goals. Productivity would likely increase if employees are adequately rewarded when they perform well especially on specific tasks accomplishments. Also, social and sporting activities should be introduced into the system, to make employees feel more relaxed at work and then have a sense of belonginess. Good worklife programmes are proven to have a positive impact on work productivity and are an important factor in recruiting and retaining the very best employees.

According to the Business for Social Responsibilities (2006), Work Life Quality Programme can increase productivity. It states that studies have shown that programme which help employees to balance work and their lives outside work can improve overall productivity. It stressed further that a company's recognition and support (through its stated values and policies) of employee's outside commitments, interests and pressures can help to relieve employees' external stress. This allows them to focus on their jobs during the workday and helps to minimize absenteeism. The result can be both enhanced productivity and strengthened employee commitment and loyalty.

In Canada, productivity has been negatively affected by absenteeism due to work-life conflict. It was reported by Duxbury and Higgins (2003) that, the majority of Canada's largest employers cannot be considered to be best practice employers. High job stress and absenteeism due to ill health have become more problematic over the past decade. Job satisfaction and organisational commitment have also appeared to decline, given the fact that workloads and work life conflict have increased over the same time period.

How an employee feel about their organisation and their job has more to do with the type of work being done and the work environment than the demands outside of work. In other words, it is what you do within the work setting and how you are treated at work that influences key organisational outcomes. It was reported that the direct costs of absenteeism due to high work-life conflict are approximately 3 to 5 billion per year. Wyatt and 
Wah (2001) also affirmed that, in North America, Europe and Japan, QWL has been quite well received as an approach leading to greater democratization and humanization of the work place as well as to greater productivity on the part of the work force.

Furthermore, Matanmi (2007) has clearly stated that the working environment remains a central variable in the reckoning and evaluation of performance. But if the pursuit of organisational goals are not harmonized with the demands of the work environment, such goals are hardly achievable. An organisation's management must squarely address the often impelling emergent problems of the working environment, including the conditions of employment such as, work scheduling, working hours, noise pollution, prolonged darkness due to power failure, monotony and so forth. It is for this reason that the managements of work organisations in Nigeria, should consciously employ rational environment, if the numerous goals of corporate organisations are to be wholly attainable. Matanmi further noted that, one of the contemporary challenges of an organisation's management is how to maximize the value-added productivity derivable from the advances in organisational production technology, but particularly also minimize the inherent adverse impact on the quality-of-worklife, and the changing needs and aspirations of employees in the increasing complex world of work. Thus, beyond sheer competitive wages, the optimization of the work environment is an antidote for organisational productivity decline.

\section{Sample and Data Collection}

This study adopted a descriptive survey research of the ex-post facto type. The population of this study is made up of all 3,640 senior staff cadre women, working in the government owned degree awarding tertiary institutions in Lagos state. Also forming part of the study population are the management level officers in those institutions. The sample elements were the two universities and the two teaching hospitals situated in Lagos, making a total of four institutions, namely, Lagos State University Teaching Hospital (LASUTH), Lagos University Teaching Hospital (LUTH), Lagos State University (LASU) and University of Lagos (UNILAG). From the population of women workers in these selected institutions, 250 were randomly selected from each institution, making a total of 1000 women for the study. The multi-stage sampling method was adopted. The purposive sampling technique was used in selecting the institutions because the two universities and two teaching hospitals selected, award degrees. The respondents were selected by convenience, using the simple random sampling technique. 715 copies of the questionnaire were returned which was $71.5 \%$ of the expected returns. From the 715,168 came from UNILAG, 151 from LASUTH, 233 from LUTH and 163 from LASU. 19 management level officers also formed part of the subject of the study.

Two levels of data collection were adopted. First is the survey questionnaire titled, 'Quality-of-Worklife Survey of Women Workers (QWLSWW). The 61 item questionnaire was sub-divided into five sections. While section A addressed the biodata of the respondents, Sections B to E required the respondents to respond to statements using a four point Likert Scale response format, looking at the relevant factors: sources of pressure, sources of satisfaction, compliance to ILO recommendations and conventions that are peculiar to women and organisational pressure factors that could influence the productivity of respondents. The second level of data collection instrument was a structured interview conducted on some management level officers of the institutions under study.

The pilot study conducted was aimed at getting the validity rate, the reliability rate, and the internal consistencies among the different sections. The factor analysis was carried out using Cronbach Coefficient Alpha, in order to get the factor loading for each item. Furthermore, a test- retest was conducted and the correlation analysis showed that the first and second tests were significantly related at $r=.815$ coefficient. The hypotheses were tested using t-test and post-hoc test.

\section{Presentation of Results and Discussion}

The analysis was done using t-test, Pearson's Product Moment Correlation, Analysis of Variance with the Post Hoc Tests, to establish the significant differences and relationships between variables and factors.

\subsection{Hypothesis Testing}

\subsubsection{Hypothesis One}

There is no significant relationship between QWL and sources of pressure of women workers in tertiary institutions in Lagos State.

In testing this hypothesis, the data generated from Section B and C of the questionnaire were applied. Pearson's Product Moment Correlation Coefficient Statistic was used for the analysis (see table 1). 
Table 1. Correlations between Quality-of-Worklife and Source of Pressure of women workers of Tertiary Institutions in Lagos State

\begin{tabular}{|c|c|c|c|c|c|c|}
\hline Variables & $\begin{array}{l}\text { Mean score } \\
\text { of Response }\end{array}$ & $\begin{array}{l}\text { Standard } \\
\text { Deviation }\end{array}$ & $\begin{array}{l}\text { Sample Size } \\
\text { (N) }\end{array}$ & $\begin{array}{l}\text { Correlation } \\
\text { Coefficient (r) }\end{array}$ & $\begin{array}{l}\text { Level of } \\
\text { Significance } \\
\text { (P) }\end{array}$ & Remark \\
\hline $\begin{array}{l}\text { Quality of } \\
\text { worklife }\end{array}$ & 99.0825 & 15.38789 & 715 & $.518 * *$ & .000 & Significant \\
\hline $\begin{array}{l}\text { Source of } \\
\text { Pressure }\end{array}$ & 22.0713 & 6.94409 & 715 & & & \\
\hline \multicolumn{7}{|c|}{$\begin{array}{l}\text { Decision: A correlation co-efficient of } .518 \text { is regarded as positively high relationship. In addition, Since ' } \mathrm{r} \text { ' } \\
\text { calculated }=.518^{* *} \text { at level of }\end{array}$} \\
\hline
\end{tabular}

\subsubsection{Hypothesis Two}

There is no significant relationship between QWL and Organisational Pressure Of Women Workers in Tertiary Institutions in Lagos State.

Testing this hypothesis would require the use of Pearson Product Moment Correlation Coefficient (PPMCC) statistical tool for the analysis (see table 2).

Table 2. Significance of Correlation between Quality-of-Worklife and Organisational Pressure of Women Workers in the Tertiary Institutions in Lagos State

\begin{tabular}{lcccccc}
\hline Variables & $\begin{array}{l}\text { Mean score } \\
\text { of Responses }\end{array}$ & $\begin{array}{l}\text { Standard } \\
\text { Deviation }\end{array}$ & $\begin{array}{l}\text { Sample } \\
\text { Size (N) }\end{array}$ & $\begin{array}{l}\text { Correlation } \\
\text { Coefficient (r) }\end{array}$ & $\begin{array}{l}\text { Level of } \\
\text { Significance } \\
(\mathrm{P})\end{array}$ & Remark \\
\hline QWL & 99.0825 & 15.38789 & 715 & $.771^{* *}$ & .000 & Significant \\
$\begin{array}{l}\text { Organisational } \\
\text { Pressure }\end{array}$ & 36.0531 & 11.73016 & 715 & & \\
\hline
\end{tabular}

\subsubsection{Hypothesis Three}

There is no significant difference in the level of compliance to the ILO conventions as it affects women workers in the different tertiary institutions in Lagos State.

Four tertiary institutions were involved in this study and in order to know if there is any significant difference, or not, in the level of compliance to the ILO conventions, between the four institutions, a Univariate Analysis of Variance was conducted.

Table 3. F-ratio Test of Significant Difference in the Level of Compliance to ILO Conventions and Recommendations as It Affects Women in the Four Tertiary Institutions in Lagos State

\begin{tabular}{lllllll}
\hline Source & Type III sum of squares & df & Mean Square & F & $\begin{array}{l}\text { Level of } \\
\text { Significance }\end{array}$ & Remark \\
\hline Corrected & $2682.327 \mathrm{a}$ & 3 & 894.109 & 79.752 & .000 & \\
Model & & & & & & \\
Intercept & 186997.373 & 1 & 186997.373 & 16679.590 & .000 & \\
Institutions & 2682.327 & 3 & 894.109 & 79.752 & .000 & \\
Error & 7971.127 & 711 & 11.211 & & \\
Total & 208543.000 & 715 & & & \\
Corrected Total & 10653.455 & 714 & & &
\end{tabular}


The table shows that the $\mathrm{F}_{\text {ratio }}$ P.000 is $<$ P.05 level of significance thus indicating that a significant difference was found and as such we do not accept the $\mathrm{H}_{\mathrm{o}}$.

In addition to this finding, the Post- Hoc test showing the multiple comparison among the institutions revealed that even-though a significant difference was found among the four institutions, LASU and UNILAG did not have significant difference between them on this issue of ILO compliance. (see table 4).

Table 4. Multiple Comparisons between the Four Institutions on Level of Significant Difference in ILO Compliance

\begin{tabular}{lllllll}
\hline $\begin{array}{l}\text { i. } \\
\text { Institution }\end{array}$ & $\begin{array}{l}\text { J. } \\
\text { Institution }\end{array}$ & $\begin{array}{l}\text { Mean } \\
(\mathrm{i}-\mathrm{j})\end{array}$ & $\begin{array}{l}\text { Difference } \\
\text { UNILAG }\end{array}$ & $\begin{array}{l}\text { Standard } \\
\text { Error }\end{array}$ & $\begin{array}{l}\text { Significance } \\
\text { Level }\end{array}$ & \multicolumn{2}{c}{\begin{tabular}{l} 
95\%Confidence Interval \\
\cline { 5 - 6 }
\end{tabular}} & LASUTH & $4.2685^{*}$ & .37547 & .000 & $\begin{array}{l}\text { Lower } \\
\text { bound }\end{array}$ & $\begin{array}{l}\text { Upper } \\
\text { bound }\end{array}$ \\
& LUTH & -.9441 & .33889 & .052 & -1.8938 & .0055 \\
& LASU & .1392 & .36812 & .986 & -.8923 & 1.1708 \\
LASUTH & UNILAG & $-4.2685^{*}$ & .37547 & .000 & -5.3207 & -3.2164 \\
& LUTH & $-5.2126^{*}$ & .34980 & .000 & -6.1928 & -4.2324 \\
& LASU & $-4.1293^{*}$ & .37819 & .000 & -5.1891 & -3.0696 \\
LUTH & UNILAG & .9441 & .33889 & .052 & -.0055 & 1.8938 \\
& LASUTH & $5.2126^{*}$ & .34980 & .000 & 4.2324 & 6.1928 \\
& LASU & $1.0833^{*}$ & .34190 & .019 & .1252 & 2.0414 \\
\multirow{2}{*}{ LASU } & UNILAG & -.1392 & .36812 & .986 & -1.1708 & .8923 \\
& LASUTH & $4.1293^{*}$ & .37819 & .000 & 3.0696 & 5.1891 \\
& LUTH & $-1.0833^{*}$ & .34190 & .019 & -2.0414 & -.1252 \\
\hline
\end{tabular}

Based on observed means

$*$ The mean difference is significant at the .05 level

\subsubsection{Hypothesis Four}

There is no significant difference in the Quality-Of-Work life of Women Workers in the different tertiary institutions in Lagos State.

The mean response on quality-of-work life could vary from one institution to another, but with tests of 'Between-Subject-Effects', one would know if there, indeed, is a significant difference. A univariate Analysis Of Variance was applied (see table 5).

Table 5. The Test of Between-Subject-Effects of Significant Difference in the QWL of Women Workers in the Four Institutions.

\begin{tabular}{|c|c|c|c|c|c|c|}
\hline Source & $\begin{array}{l}\text { Type III Sum of } \\
\text { Squares }\end{array}$ & $\begin{array}{l}\text { Degree of } \\
\text { Freedom }\end{array}$ & Mean Square & $\mathrm{F}$ & $\begin{array}{l}\text { Level of } \\
\text { Significance }\end{array}$ & Remark \\
\hline $\begin{array}{l}\text { Corrected } \\
\text { Model }\end{array}$ & $29470.749 a$ & 3 & 9823.583 & 50.034 & .000 & \\
\hline Intercept & 6893773.590 & 1 & 6893773.590 & 35112.000 & .000 & \\
\hline Institution & 29470.749 & 3 & 9823.583 & 50.034 & .000 & $<.05$ \\
\hline Error & 139595.382 & 711 & 196.337 & & & \\
\hline Total & 7188468.000 & 715 & & & & \\
\hline $\begin{array}{l}\text { Corrected } \\
\text { Total }\end{array}$ & 169066.131 & 714 & & & & \\
\hline
\end{tabular}

$\mathrm{a}=\mathrm{R}$ Squared $=.174$ (Adjusted R Squared $=.171$ ) 
The total revealed that at the P.05 level of significance, the $\mathrm{F}_{\text {ratio }}$ indicated P.000. Since $\mathrm{F}_{\text {ratio }}$ P. $000<$ P.05, it implies that a significant difference was found and as such we do not accept the Ho.

Nonetheless, the Post-Hoc-Test which shows the multiple comparisons of the QWL between each of the institutions shows that there is no significant difference between LASU and UNILAG, LASU and LUTH, then, LUTH and UNILAG (see table 6).

Table 6. Multiple Comparison between the Four Institutions on Level of Significant Difference in QWL of Women Workers

\begin{tabular}{lllllll}
\hline i.Institution & J. Institution & $\begin{array}{l}\text { Mean } \\
(\mathrm{i}-\mathrm{j})\end{array}$ & & Difference & $\begin{array}{l}\text { Standard } \\
\text { Error }\end{array}$ & \multicolumn{2}{l}{$\begin{array}{l}\text { Significance } \\
\text { Level }\end{array}$} & \multicolumn{2}{l}{$\begin{array}{l}95 \% \text { ConfidenceInterval } \\
\text { Lower } \\
\text { bound }\end{array}$} & $\begin{array}{l}\text { Upper } \\
\text { bound }\end{array}$ \\
\hline \multirow{2}{*}{ UNILAG } & LASUTH & $-15.8371^{*}$ & 1.57128 & .000 & -20.2401 & -11.4341 \\
& LUTH & -1.5746 & 1.41821 & .745 & -5.5487 & 2.3995 \\
& LASU & 1.1812 & 1.54052 & .899 & -3.1357 & 5.4980 \\
\multirow{2}{*}{ LASUTH } & UNILAG & $15.8371^{*}$ & 1.57128 & .000 & 11.4341 & 20.2401 \\
& LUTH & $14.2625^{*}$ & 1.46386 & .000 & 10.1604 & 18.3645 \\
& LASU & $17.0182^{*}$ & 1.58264 & .000 & 12.5834 & 21.4531 \\
\multirow{3}{*}{ LUTH } & UNILAG & 1.5746 & 1.41821 & .745 & -2.3995 & 5.5487 \\
& LASUTH & $-14.2625^{*}$ & 1.46386 & .000 & -18.3645 & -10.1604 \\
& LASU & 2.7558 & 1.43079 & .295 & -1.2536 & 6.7651 \\
\multirow{3}{*}{ LASU } & UNILAG & -1.1812 & 1.54052 & .899 & -5.4980 & 3.1357 \\
& LASUTH & $-17.0182^{*}$ & 1.58264 & .000 & -21.4531 & -12.5834 \\
& LUTH & -2.7558 & 1.43079 & .295 & -6.7651 & 1.2536 \\
\hline
\end{tabular}

Based On Observed means

* The mean difference is significant at the .05 level

\subsection{Findings on Interview}

Some of the management level officers that were interviewed identified new techniques that could relief women workers of stress at work and home. They include:

- $\quad$ Flexible Working Hours

- Work Sharing

- $\quad$ Sports and Recreation Facilities

- $\quad$ Provision Of Tea and Coffee

- $\quad$ Stress Management Course for Staff

- Information Technology Equipments

- $\quad$ Time Management Coping Mechanism

- Improved Reward System

- Maternity Leave Allowances

- Tele commuting

- On-Site Day Care

- Supermarket, Saloon and Mini market on Premises

- Domestic Chore Support Equipments like Deep freezer, Microwave, Washing Machine etc.

- Internet Provision for On-line Learning At Home

- $\quad$ Spouse Support

- $\quad$ Maintaining Health Balance Between Work And Play 
- $\quad$ Create Time for Family

- Create Time for Prayer and Meditation

- Employ Domestic Assistants

- $\quad$ Reduce Working Hours

- $\quad$ Nursing Mothers Not To Be Placed Where There Is Pressure At Work

- Increase Allowances To Enable Payment For Necessary Supportive Equipments.

Based on the knowledge of the above techniques, suggestions were made on how to increase the QWL of women workers in tertiary institutions, which includes;

- $\quad$ Flexible Working Hours

- $\quad$ Encourage Inclusion Of More Women At The Top Management Level.

- Staff Welfare such as; Accommodation, Transportation.

- $\quad$ Training And Re-training

- $\quad$ Facilities and Equipments Required For Working To Be Put In Place.

- $\quad$ Security Of Lives At Work

- $\quad$ Pregnant Women Not To Go On Night Shift.

- Maternity Leave To Be Six Months

- Recreational Facilities

- $\quad$ Right-Sizing Of Workforce i.e. No Shortage of staff

- $\quad$ Staff Emoluments To Be Given As At When Due

- Promotions To Deserving Staff To Be Given As At When Due

- Pensioners should Be Given Their Entitlements As At When Due

- $\quad$ Equal Opportunity To Be Given To Everybody

- $\quad$ Flexible Leave Policy

- Maternity Leave Allowance

- $\quad$ Upgrade Health Care Center By Making Drugs Available

- $\quad$ Adoption Of Per-Hour Pay System

- Workload To Reduce For Nursing Mothers

- Recognition Of Outstanding Workers Regularly

- Women workers To Form Association That Would Collectively Address Their Common Problems.

- $\quad$ Regular Power and Water Supply

\subsection{Discussion}

Some factors conglomerate into the concepts called 'Quality-Of-Worklife'. Those considered in this study were sources of pressure or stress, organisational pressure factors, sources of satisfaction and organisational compliance to the relevant ILO conventions and recommendations. $49.7 \%$ of the respondents found the lack of available child-care centre close to their workplace as a source of pressure. This agrees with the outcome of the study conducted by the Women's Initiative Steering Committee of Duke University (2003). They recommended a 'family friendly' workplace to ease the stress of women workers, especially those with child-care responsibilities. Moreover, the outcome of this study on child-care is supported by Buffardi, Baughman et al (2003), whose survey's finding identified child-care issues as a source of stress for employees. In addition, Wood (2003)'s survey outcome gave a support to this study when it recommended among other things, the need to create a 'back-up child-care facility and expand capacity and availability for child care for employees in the Vanderbilt's Medical Centre.

Long working hours or excess work demands characterizes the workload related job stress. $46.1 \%$ acknowledged workload as a considerable high source of pressure. This is consistent with previous studies of Adepoju (2001) Amabile (2002) Duxbury and Higgins (2003, 2005) Ferguson-Pare (2006) and Matanmi (2007). This is common in most government parastatals, hence, the general suggestion by a number of researchers (Jeremigbe,1992 
American Business Collaboration,2006 and Business for Social Responsibilities, 2005),that work scheduling, telecommuting and flexible time should be encouraged.

The items that attracted high response of non satisfaction were salary/wages, health care benefit, safety conditions for workers, comfortability of work environment and access to internet services paid for by work organisation. The issue of non-satisfaction with salary is general and commonly agreed upon by most researchers. Matanmi (2007), American Business Collaboration (2006) Duke University (2003) and Wyatt and Wah (2001), all mentioned good pay as an integral part of the factors responsible for job satisfaction. As a result of this non-satisfaction, a lot of agitations from workers do take place from time to time in form of sit-in, overtime-ban, picketing, work-in and ultimately, strike actions.

The strength of communication between the employer and the employee, and the involvement of the employees in the decisions that would affect them, goes a long way in determining the quality of worklife of the employees. The outcome of this study revealed that some policies made by the sampled institutions were not in the favour of their women workers and as such they were not pleased with such policies. If these workers had been involved in the formulation of such policies, (while organisations have clear values which are understood at all levels and policies had been properly communicated to them,) then, they would not feel bad or cheated by such policies. It was in this light that Vanderbilt Medical Centre as reported by Wood (2003), in an attempt to address the issue of QWL formed a task force which recommended that more communication about Vanderbilt's mission, vision, financial performance, core values and strategic goals be made, so that their workers would know more about what is happening and how it affects them. Proper communication system within the organisation and participatory decision-making as a form of encouraging or enhancing high quality of worklife has also been supported by the studies of Amabile (2002) Wright (2002) Ogbimi (2003) UN, Department of Economics (2004), Gilbert (2006) and Niombo (2006) and recommendations on this was corroborated by the interview outcome.

The hypotheses that stated that there is no significant relationship between QWL and Organisational Pressure of Women Workers and between QWL and Sources of Pressure respectively were not accepted. In other words, there is a relationship between QWL and Organisational Pressure on one hand and QWL and Sources of Pressure on the other hand. Once the organisational pressure is high, the QWL is affected negatively and vice versa. The same applies to QWL and sources of pressure. A great number of literature and research studies have supported this finding. Giving support to this assertion were Martino (1993) Oshodi (1997) Adepoju (2001) UN Department of Economic And Social Affairs and, Division For Sustainable Development (2004). The general conclusion on this issue was that, to improve on the QWL of women workers, definite efforts should be made to reduce the sources of pressure both at home and at work and those factors leading to organisational pressure should be addressed objectively.

The level of compliance to ILO conventions and recommendations was common to all the sampled institutions and it was also found that all the sampled institutions did not differ significantly in the Quality of worklife of their women workers. From this finding, it could be said that the Nigerian women workers in tertiary institutions are faced with similar Quality of worklife experiences.

\section{Conclusion}

From the foregoing, some conclusions could be arrived at as being precipitated by the findings of this study and supports received from similar studies. It could be said emphatically that for organisations like tertiary institutions to achieve high level Quality-of-Worklife for its women workers, it has to pay considerable attention to those factors that have been recognised or identified as creating pressure or stress to the workers. Such factors include not having child-care centres on-site, heavy workload and long-working hours. Also, the factors that do not contribute to women workers adequate satisfaction on the job should be seriously considered. For example, their non-participation in decisions concerning their well being, lack of access to the internet at work, inadequate health care facilities for workers and their dependents, non-recognition for high performance and so forth.

The study has also enabled the conclusion that there is a strong positive relationship between QWL and organisational pressure on the one hand and QWL and sources of pressure on the other hand. Hence, the level of QWL of women workers is greatly dependent on the amount of the organisational pressure and other sources of pressure they are faced with.

It could also be concluded that all the tertiary institutions in Lagos State, whether educational or health oriented, do differ significantly in the level of QWL their women workers enjoy. 


\subsection{Policy Implications}

The Nigerian Legislatures must necessarily enact laws that make compulsory the provision of QWL programmes in all the public and private institutions and ensuring compliance through a monitoring body. In addition, every organisation should be made to have a unit attached to the Human Resource Department specifically addressing QWL matters in their organisation.

QWL surveys should be carried out on a regular interval or annually or every other year. The ILO review their recommendations and conventions regularly, hence managers should get such information for implementation. Day-Care centres should be situated within the premises of the institution and Telecommuting should be practiced where applicable, to cut down loss of hours in traffic and the stress associated with it. Women should be given a voice in matters that concerns them by the practice of Participatory Decision Making method. Flexible time and job sharing should be allowed in order for women workers to spend quality time with their families.

This study certainly has not covered all variables QWL is dependent on, therefore further studies involving such other variables, many more other institutions/organisations would be worthwhile.

\section{References}

Adekoya, S. O. A., \& Adetoro, J. A. (2001). Fundamentals of statistics and research methodology. Lagos: Tunwobi Service

Adepoju, T. L. (2001). Management of stress in education industry: implications for education managers. African Journal of Educational Managementm, 9(1), 45-55.

Amabile, T. (2002). Time pressure and creativity: why time is not on your side. Working_Knowledge For Business Leaders. Retrieved from http: hbswk.hbs.edu/item/3030.html.28/8/2006

Buffardi, L. Baughman, K., \& Morse, K. (2003). Quality of worklife survey results-2003, Retrieved from http://www.gmu..edu/qwl/archive/qw/103-104/

Duxbury, L., \& Higgins, C. (2003). Worklife conflict in canada in the new millennium: a status report. Retrieved from http://www.phac-aspc.gc.ca/publicat/work-travail/report2/index.html

Duxbury, L., \& Higgins, C. (2005). Report four: who is at risk? predictors of work-life conflict. Retrieved from http://www.phac-aspc.gc.ca/publicat/work-travail/report/index.html

Gallagher, S. P. (2001). A guide to balancing work and personal life. State Bar News, 43(3), p43.

Gilbert, S. J. (2006). Do I dare say something? Working Knowledge for Business Leaders. Retrieved from http://hbswk.hbs.edu/item/item/5261.html 28/8/2006

International Labour Organisation. (1998). Women in management: it's still lonely at the top. World Of Work Magazine, 23, Feb. 1998, Geneva; ILO.

International Labour Organization. (1993). International labour convention and_recommendation 1919-1991, Geneva: ILO.

Jeremigbe, H. I. (1992). Constraints to women's employment and advancement to management positions in Africa. Nigerian Management Review, 7(1\&2), 463-470. Retrieved from http://hum.sagepub.com/cgi/content/abstract/58/1/33

Martin, E. J. (2006). Labour-management relations, collective bargaining, and the public sector collaborative solutions in Alameda, California. Public Administration Quarterly, 13, Retrieved from http://www.pamij.cm/8-2/pam8-2-2.html

Martino, V. D. (1993). Cutting the cost of stress. World of Work Magazine, 2, Feb. 1993, Geneva; ILO.

Matanmi, O. O. (2007). Employment relations that endure: lesson for Nigeria. $31^{\text {st }}$ Inaugural Lecture, Lagos State University.

Niombo, S. (2006). 'Why Are Congolese Women Absent from Decision-Making in ICTS?" in APC African-Women Programme http:www.genderit.org/en/index.shtml

Ogbinmi, R. I. (2003). Participatory Decision Making In some Nigerian Tertiary Hospitals: The Option of Committee Members. Nigerian Management Review, 14(1\&2), 1094 -1107. 
Oshodi, A. O. (1997). Relating Human Resource Management Policies And Practices To Gender Structure Of Industry: Implications For Workforce Stability In Nigeria (Unpublished MBA Project of Lagos State University).

Seguret, M. (1993). Motherhood, Family Career. World of Work Magazine, 2, Feb. 1993, Geneva: ILO.

UN Department of Economics and Social Affairs. Division For Sustainable Development (2004). 'Global Action For Women Towards Sustainable And Equitable Development. Retrieved from http://www.un.org/esa/sustdev/documents/agenda21/english/agenda21 chapter 24.htm

Unauthored (2003). "Managing Stress" in The Trainer $2^{\text {nd }}$ ed. Lagos State: Training Department Office Of Establishment and Training. pp. 14-16

Unauthored. (2006). American Business Collaboration For Quality Dependent Care. Retrieved from http://www.abcdependentcare.com/docs/current-news.shtml

Unauthored. (2006). Work-Life Quality" in Business for Social Responsibility. Retrieved from http:www.bsr.org/CSR Resources? Issue Brief Detail. Cfm? DocumentID-50965

Vukor-Quarshier, T. (2000). Moving Up the Corporate Ladder: Useful Hints for Women Executives. Management in Nigeria, A Journal Of Nigerian Institute of Management, 38(2), 19-32.

Weinstein, E. (2004). Where Are the Women? Fast Company Magazine, 79, 52. Retrieved from http://www.fastcompany.com/magazine/79/women.html

Wyatt, T. A., \& Wah, C.Y. (2001). Perspectives of QWL: a Study of Singaporean Employees Development. Research and Practice in Human Resource Management, 1(2), 59-79. Retrieved from http://rphrm.curtin.edu.au/2001/issue2/qwl.html 